TP Periodica Polytechnica

Social and Management Sciences

22(1), pp. 21-27, 2014

DOI: $\underline{10.3311 / P \text { PSO } 2151}$

http://www.pp.bme.hu/so/article/view/2151

Creative Commons Attribution (i)

RESEARCH ARTICLE

\section{Step by Step Towards Mandatory Green Public Procurement}

\author{
Orsolya Diófási / László Valkó
}

RECEIVED 14 June 2013; ACCEPted AFter REVISION 29 OCtOBER 2013

\section{Abstract}

Green Public Procurement (GPP) is one of the keyenvironmental management tools to reach sustainable consumption patterns, drive innovation and widen the market for eco-technologies. GPP is when procurers take environmental issues into account when buying goods or services. Buying green is one of the most active and demonstrative ways of enhancing environmental protection; it is a tool that every individual, public authority and private company can use to promote and achieve sustainable consumption. This article will focus on defining a possible purchasing strategy for public authorities, which is using GPP. This paper presents a systematic approach model using GPP as a driver of sustainable consumption while highlighting the importance of its policy background. A short analysis of EU Member States' GPP action plans will also be introduced. The upcoming government act on GPP in Hungary will be presented with a practical example of green tendering by the National Bank of Hungary.

\section{Keywords}

green procurement - GPP - green public procurement . national action plans $\cdot$ Hungary

\section{Orsolya Diófási}

Department of Environmental Economics, Budapest University of Technology and Economics, Magyar tudósok krt. 2., H-1117 Budapest, Hungary email: o.diofasi@survive.hu

\section{László Valkó}

Department of Environmental Economics, Budapest University of Technology and Economics, Magyar tudósok krt. 2., H-1117 Budapest, Hungary

\section{Introduction}

Green Public Procurement (GPP) has been defined in the Communication "Public procurement for a better environment" as "a process whereby public authorities seek to procure goods, services and works with a reduced environmental impact throughout their life cycle when compared to goods, services and works with the same primary function that would otherwise be procured." [7] The goal is to reduce the impact of purchases on the environment $\left(\mathrm{CO}_{2}\right.$ emissions, toxic material, amount of waste, etc) and human health. GPP is a voluntary instrument in most Member States, which means public authorities can determine the extent to which they implement the concept.

"Public authorities are major consumers in Europe: they spend approximately 2 trillion euros annually, equivalent to some $19 \%$ of the EU's gross domestic product. By using their purchasing power to choose goods and services with lower impacts on the environment, they can make an important contribution to sustainable consumption and production. Green purchasing is also about influencing the market. By promoting and using GPP, public authorities can provide industry with real incentives for developing green technologies and products. In some sectors, public purchasers command a large share of the market (e.g. public transport and construction, health services and education) and so their decisions have considerable impact." [20]

Taking into account the environmental aspects of GPP by public purchases the following advantages can be realized: GPP sets the example for industry, drives innovation of ecoproducts, gives an opportunity to develop existing purchasing practices, generates savings with the use of life cycle costing (LCC), helps promote environmental cooperation among employees, results in a positive image, and can be integrated with other environmental management tools, and systems (ISO14001, EMAS). Altogether GPP is an active and demonstrative practice of environmental protection.

The above listed advantages of GPP provide a perfect example of its functional benefits as highlighted below. The public authorities that are implementing environmentally, socially and economically responsible purchasing practices, and are 
actively taking part in creating a sustainable future have higher degree of respect from the public. Sustainability campaigns for the citizens and sustainable business incentives for the private companies can further enhance trust between the consumer and industry. Even political and PR advantages can come from a well maintained and effective green procurement system, since it has direct implications on most of the stakeholders in connection with the organization.

\section{GPP as a driver of sustainable consumption}

The concept of GPP is based on purchasing green products and services and searching for the most economically advantageous offer. This means that the three pillars of sustainability should be taken into account: best green solution throughout the lifecycle of the product or service, the most socially advantageous solution and the life cycle costing approach on the economic side. The economic advantages/disadvantages of GPP are a very common debate topic between experts and subject of further research with best practice examples.

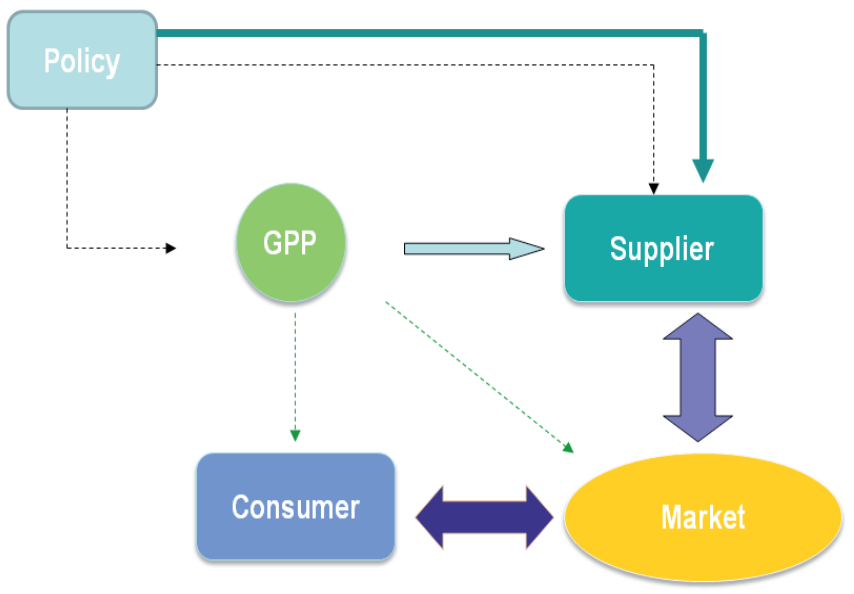

Fig. 1. The effect of GPP on the actors of economy (Source: own work)

It should be mentioned that sustainable consumption has a use-phase aspect as well [26]. It isn't solely focused on production and purchasing but the behavior and the way of using the products should also be considered. (For example, smart use of electrical equipment and power consumption in offices is very much an individual behavioral and awareness issue) This user side approach can make GPP even more effective from the economic and environmental point of view.

The following model shows how GPP can drive sustainable consumption.

The policy tools, like regulations and directives have a direct influence (solid line) on suppliers, but there are voluntary tools as well, like eco-labeling, which influence and further sustainable production (dashed line).

The policies have an influence on the use and implementation of GPP as well. So far the EU has used relatively light, advise-like, voluntary tools towards the Member States, probably due to lobbyist actions. On the other hand there are policy recommendations for the EU to make green public procurement mandatory for all authorities in the Member States [16], which would result in even stronger effect on the suppliers and the market. In the next part of the article the GPP Action Plans of the EU Member States will be analyzed, focusing on mandatory GPP actions.

GPP, just as policies has a very direct effect on the suppliers. Authorities using the GPP concept are requiring environmentally friendly goods and services. Suppliers should meet the criteria and take the challenge: design their products and services in a way that is innovative and lives up to the aim of sustainable production. This is the only way they can keep their competitive advantages. Supplier and eco-market interactions had already been analyzed by the authors in a previous article [9].

Since suppliers have a strong connection with the market, in form of shared interaction, GPP has an indirect effect (dashed green line) on the market via suppliers. If a supplier has numerous green products in stock due to public tendering it will evidently offer these products to other customers as well. With many green products and services the overall market demand can be transformed as well.

The market is in even stronger connection with the consumers and the interaction is crucial, so GPP and policies should align with the consumers' preference as well. This is a phenomenon called choice editing: the unsustainable goods and services are no longer available in the market, so there is no chance of buying them. Together with the example setting function, GPP has a very strong indirect influence on consumers.

\section{The level of GPP in Europe and it's policy background}

Below the EU's GPP policies will be introduced along with a short analysis of the EU Member States' GPP action plans, with special emphasis on mandatory GPP actions. The current GPP policies at EU level are mainly of a voluntary nature. The four main policy tools according the European Environmental Bureau [17] are as follows:

(1) A Communication of the Commission on Integrated Product Policy (2003) which "encourages" all Member States to develop National GPP Action Plans by 2006

(2) The Sustainable Development Strategy (2006) which aims to increase the average level of GPP in the EU to the level of the best performing Member States. It also identifies activities to be carried out by the Commission to promote GPP.

(3) The Communication on GPP of 2008 which concretizes the existing target of the Sustainable Development Strategy by proposing that "by the year $2010,50 \%$ of all tendering procedures should be green".

(4) Development of common GPP criteria in the framework of a "GPP Toolkit" that is provided by the Commission. 
These criteria are developed to serve as a template for public purchasers and to define minimum standards for GPP in order to assess the level of GPP in the EU. [17] These criteria are in strong connection with ecolabelling, since the development of the GPP and EU Ecolabel criteria are done in a parallel process under the supervision of the European Commission and GPP Advisory Group which consists of representatives of the Member States and other stakeholders (NGOs, industry representatives). [20]

The EU 2020 Strategy also highlights that "public authorities have to lead by example. Public procurement rules should insist on efficiency conditions to increase energy savings and spread innovative solutions, notably in buildings and transport." [6]

So far only three product groups (sectoral selection) are selected on the EU level for mandatory GPP.

Regulation 106/2008 ('Energy Star' labeling program for office equipment) obligates central government contracting authorities to "specify energy - efficiency requirements not less demanding than" those used "to determine qualification of energy - efficient office equipment products" for use of the Energy Star label. [23]

Directive 2009/33 (promotion of clean and energy - efficient road transport vehicles) obligates contracting authorities to "take into account the operational lifetime energy and environmental impacts" [13] of the vehicles; It allows three options: technical specifications, award criteria, life - time costing [15].

With regard to buildings from 2013 at the latest, minimum energy performance requirements will need to be applied in all new build and major renovation projects. From 1 January 2019 all new buildings occupied and owned by public authorities must be "nearly zero-energy buildings". [14][4]

The experts' opinions on the topic are quite different. Some say that the EU should be doing more to mandate GPP, but others think that this might be premature and end up restricting buyers [19].

This is where the Member States have different opinions as well. In their National GPP Action Plans some of the states introduced mandatory GPP criteria. According to the Communication of the Commission on Integrated Product Policy (2003) all Member States should have developed National GPP Action Plans by 2006.

A recent study, "The Uptake of Green Public Procurement in the EU 27" clearly shows that this is far from the case. [24]

According to the recent reporting from May 2013 the stateof-the-art of National Action Plans (NAP) [20] is the following:

NAP or equivalent document adopted (22 Member States): Austria, Belgium, Bulgaria, Cyprus, Czech Republic, Denmark, Finland, France, Germany, Ireland, Italy, Latvia, Lithuania, Malta, Netherlands, Poland, Portugal, Slovakia, Slovenia, Spain, Sweden, UK

No existing NAP (5 Member States): Estonia, Greece, Hungary, Luxembourg, Romania

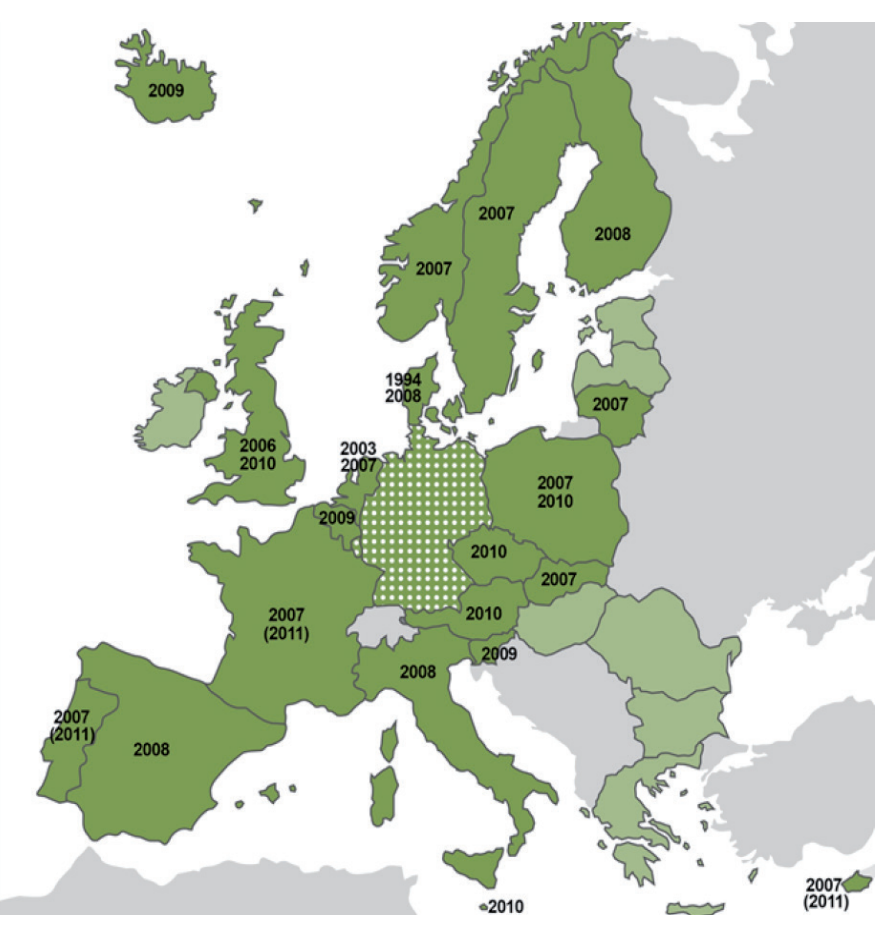

Fig. 2. National GPP Action Plans in the EU (Source: [24])

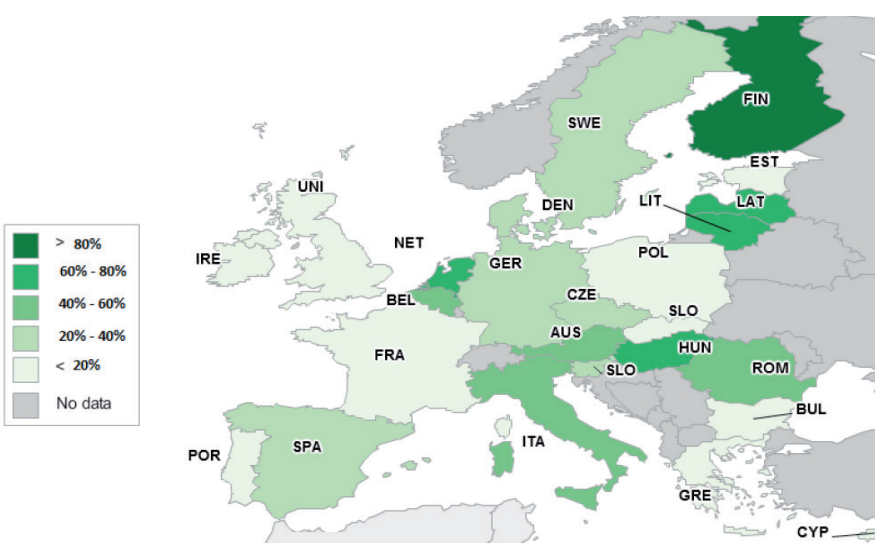

Fig. 3. GPP by value indicator (Source: [24])

Even though a few countries, unfortunately including Hungary - do not have an action plan, GPP is applied in all the countries on different levels. The uptake of GPP can be measured on the quantitative level by two indicators: the monetary value and the number of green tenders compared to non-green tenders.

The first indicator, the value, gives the percentage of the amount spent on green public procurement contracts, compared to the total amount spent on non-green contracts. The second indicator shows the percentage of GPP of total public procurement, in terms of the number of contracts. To measure the number of actual green purchases it is important to use the number of contracts, not tenders [25].

The two indicators show significant differences between the countries. For example, by the value indicator Hungary has great scores. Statistics show that the value of GPP is between 
60-80 percent of the money spent on public procurement. However, the number of contracts show that only $20 \%$ of the contracts included green criteria. The two indicators differ quite a lot. This is due to product group selection and individual, specific contracts. In Hungary, for example, more than 800 light fixtures were installed to provide Liberty Bridge's ornamental lighting, 584 of which are LED lights. This amounts to installed power of 40.7 kilowatts, of which the LEDs account for 13.1 kilowatts. The project was carried out in 2009 at a cost of $€ 1.66$ million. In the following years GPP criteria had been applied for procurement of recycled paper (2009-2011, €220,000) and the construction of a highway noise barrier (2009-2010, €4 million). [18]

This case is a good example of the difference between the two indicators (based on procurement value and on the number of contracts). From an environmental point of view, big construction and reconstruction projects have great environmental impacts, so if green criteria is used, it should appear in the figures. On the other hand, because of this one project, it might appear that Hungary is already very much ahead concerning GPP, however this is only be based on one procurement example. For this reason, both indicators are equally important to indicate the accurate level of GPP in a certain country. The value indicator could be more relevant from an environmental point of view, while the number of contracts indicator is to show the general implementation of GPP, the change in mentality of public purchasers. [24]

Based on the statistical data above, it is clear that the level of GPP does not depend significantly on mandatory actions. Only the following eight Member States use obligations: Austria, Cyprus, Czech Republic, Denmark, Germany, Lithuania, Malta, and Portugal. [22]

\section{Green Public Procurement Government Act, Hungary}

This topic is interesting because in January 2013 a draft Green Public Procurement Government Act was released and is expected to be in force by July 2013. [28] This document can be a great achievement towards a national policy framework. In the past, the following actions had been taken in order to implement GPP into the Hungarian public procurement practices [21]:

In line with the EU Directives (2004/18/CE, 2004/17/CE) aiming to clarify, simplify and modernize existing European legislation on public procurement and giving a legal base for GPP [11][12], the national Public Procurement Legislation (PPL) allowed for environmental considerations since 2006.

In 2007 the National GPP Action Plan was drafted with a market analysis and a feasibility study, giving positive results, but unfortunately was not approved till today.

In the recent PPL that came into effect in January 2012 sustainable development is listed as a priority, and the use of sustainability criteria is allowed in the awarding phase of the procurement

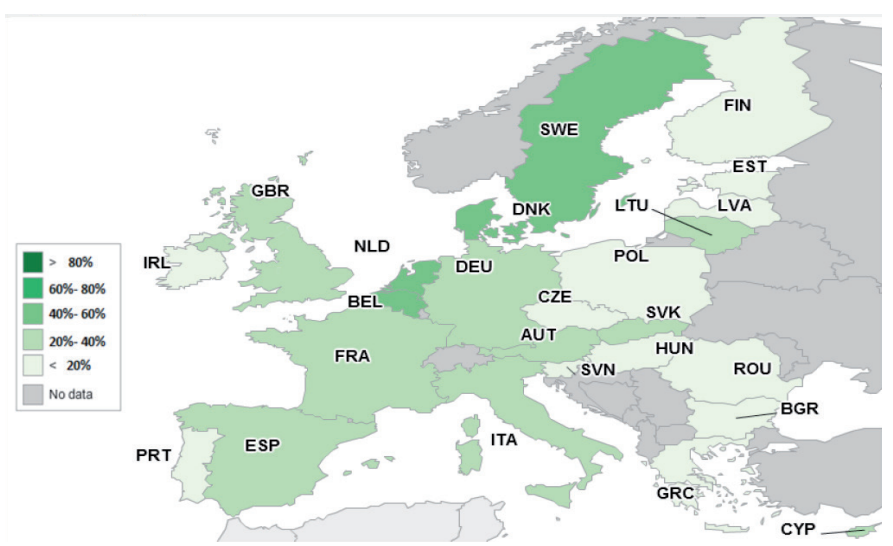

Fig. 4. GPP by number of contracts indicator (Source: [24])

process. The sustainability criteria is defined as material and energy efficiency, dematerialization, green house gas reduction, and other criteria that result in a reduced impact on the environment throughout the lifecycle of the product or service. [1]

The draft of the GPP act mandates the use of GPP for centralized procurement, for organizations managed by the government, governmental public foundations, and state-owned entities. Other organizations taking part in public procurement can also voluntarily use GPP, but they have to work according to the rules set in the act for the mandatory GPP.

It is mandatory to use GPP in the following categories:

- Paper products

- IT products

- Furniture

- Cars, buses

- Cleaning products and services

- Telecommunication devices

- Transportation services

- Food and catering

- Others (waste management, gardening, wastewater treatment etc...)

This list mainly covers those products and services that are most suitable for greening according to the literature [3], but the act leaves the possibility to have green criteria in case of other products and services. [28]

All organizations as defined by the act should have an internal GPP regulation, which must contain information on which product groups to work with and how to guarantee the environmental expertise over the process of tendering. [28] This is very important since setting the environmental criteria sometimes causes major difficulties for the procurement officers, especially since many are of them are not experts in the fields of technology and sciences. This problem can be solved with the strong cooperation and input of environmental experts, consultants and procurers. A so called performance criteria collection which contains the technical specification of environmental friendly product alternatives had already been developed. [10] 
The act highlights the phases of the procurement process where green criteria can be implemented. These include the following:

a) Technical specifications; (By defining the technical specifications public authorities have the possibility to include wide range of environmental performance standards eg. the specifications for the eco-labels. Usually the criteria of the ISO Type I labels can be inserted into the call for tender. The ISO 14024 Type I environmental labeling is a voluntary, multiple-criteria based, third party program that awards a license which authorizes the use of environmental labels on products indicating overall environmental preference of a product within a particular product category based on life cycle considerations [2]. So it is legally correct to use the eco-label criteria, but public authorities can't require having the eco-label, because that would be considered discrimination against the products that don't have the label. As long as they can prove the correspondence to the criteria they should be accepted. [8])

b) Selection criteria; (It shows weather the bidders have the necessary financial and technical competence in performing the contract. For example the contracting authorities can ask from the bidders of certain work and service contracts to take several environmental management actions for the duration of the contract to prove their ability to carry out the project. In that case companies that are EMAS or ISO14001 certified should be accepted but also other proof should be accepted to avoid discrimination. [8])

c) Exclusion criteria (Grounds for exclusion can be if the bidder had violated environmental law in the last 5 years. [28])

d) Award criteria; (The purchasing officer either chooses the bid with the lowest price or "the economically most advantageous offer". In the second case a series of award criteria should be developed which include the price, environmental and other criteria. [8])

e) Performance clauses

The performance clauses should contain at least one of the followings:

- Dematerialization

- Environmentally friendly packaging according to the 91/2006. (XII.26.) GKM decree, collection of packaging waste

- Waste collection for recycling

- construction or demolition waste recycling,

- reduced material and energy use

- reduced greenhouse gas and pollutant emission

- reduction of waste, and hazardous waste

- reduction of noise, vibration, radiation

- avoidance of air, water and soil pollution

- recycling of industrial byproducts and secondary raw materials) [28]
It is mandatory to have at least 4 green criteria in a) Technical specifications, b) Selection criteria, c) Exclusion criteria, d) Award criteria, or e) Performance clauses categories. [28] This is quite a strict resolution, but feasible. In the next part, with the good practice example this will be confirmed.

The act also states that by each GPP criteria, the process of examination should be described. This is useful for the bidder and the contracting authority since the proof of compliance is clearly stated. [28]

In line with EU public procurement legislation, contracting authorities using GPP cannot impose any requirements or conditions that restrain competition or discriminates against the bidders. The environmental criteria should be directly related to the subject of the procurement. Aiming to help the implementation of the act, the Hungarian Procurement Authority together with the minister of environmental protection will publish a brochure on the useful and recommended green criteria on products, services and construction works. [28]

\section{Good practice example from Hungary}

Before the release of the draft GPP act, the National Bank of Hungary decided to greening their purchasing practices as part of their sustainability program [27]. The Bank is EMAS certified, committed to sustainability, and has several projects on energy efficiency and renewable energies.

The plan of the Bank representatives and their green procurement consultants' was to implement green procurement step-by-step, first only for a selection of product groups under the public procurement threshold. After 6 months, the system would be evaluated and according to the results evaluation, the green procurement concept would be expanded to other purchases as well. In December 2012, the Procurement Department took part in a green procurement training program. The training was designed according to the methodology reported in a previous paper (Training methods for purchasing officers to facilitate green procurement in Hungary [20]). The selected product groups were: notebooks, taxi- and messenger services, furniture, office paper, smart phones, educational and consulting services. The training consisted of the following theoretical topics: principles of green procurement, economic and management cases, environmentally friendly products, eco-labeling, life cycle assessment. The practical module contained the setting of green criteria in the call for tender, evaluation of the tenders and measuring the effects of green procurement. The participants received ready to use performance sheets developed by the consultants for the selected product groups based on mainly Eco-label criteria.

After the beginning of this project the draft of GPP Act was released and the Bank had an opportunity to write a call for tender for a large-scale purchase of printed material above the threshold of public procurement. The management of the procurement department decided to include green criteria in this 
call, since the product group was part of their training, the criteria in their opinion did not affect the bidders significantly and there was a chance to try if the new act would be feasible in the future. The call for tender was designed completely according to the draft GPP act and can be mentioned as the first comprehensive GPP call in Hungary.

The preliminary market survey gave positive results: none of the bidders asked for extra information about eco-labeling or any other criteria and reported on being able to fulfill the environmental criteria without any problem. The call was approved by a legal proofreader on behalf of the Procurement Authority as well. Thirteen potential bidders downloading the call for tender.

The call contained the following criteria: [5]

Subject: printed brochures

Award criteria: The paper used for printing is certified by one of the following ecolabels: Blue Angel, EU Ecolabel, Nordic Swan, FSC, PEFC. For the validation of this award criterion the technical specifications of the paper should be attached. The bidder fulfilling this criterion achieves 1 point by the scoring, with a weighting share of 10 percent.

Selection criteria: Certification of ISO 14001. The Bank has used this criterion in their previous tenders as well, but in case of printing services the environmental management system has an especially important role.

Technical specifications: taking into account the environmental protection, part of the brochures will be electronic design.

Performance clauses: The contractor agrees to cooperate with the customer to follow the environmental principles of green public procurement. Especially in the following fields:

a) dematerialization,

b) eco-friendly, proper packaging and collecting of packaging waste according to the $91 / 2006$. (. XII.26) Decree.
Furthermore in case of public procurement processes, the National Bank of Hungary uses electronic invoicing, along with electronic auction where the final bids could be submitted via an electronic interface.

This call for tenders is one of the first comprehensive green public procurement tenders in Hungary and thus has great significance. As a good practice example and feasibility testing for the upcoming GPP act, this case study provides very useful supporting data.

\section{Conclusions}

According to the above described model and the international literature review, it is clear that GPP is one of the most important tools towards achieving sustainable consumption. The reports of the European Commission and some of the Member States' practices show that the concept can be used very effectively. For this reason some of them are implementing policies that mandate authorities to green their purchases. The statistics show that there isn't a clear link between mandatory GPP and the number or value of green tenders. In Hungary, the draft government act would require a certain number of public authorities to use green criteria. Even before the act came into effect, the National Bank of Hungary decided to have a green tender according to the requirements of the act. The experiences of the most comprehensive green tender in Hungary shows that the use of GPP is feasible and the key to successful implementation of green public procurement is commitment and the technical know-how.

\section{Acknowledgement}

The work reported in the paper has been developed in the framework of the project „Talent care and cultivation in the scientific workshops of BME" project. This project is supported by the grant TÁMOP - 4.2.2.B-10/1--2010-0009.

\section{References}

1 2011. évi CVIII. törvény a közbeszerzésekröl, Complex Hatályos Jogszabályok Gyüjteménye.(2013.V.26. Hatályos). http://net.jogtar.hu/jr/gen/hjegy_doc.cgi?docid=A1100108. TV\#lbj1param

2 Baranyi R., Criteria Groups in the eco-labelling process system - comparative analysis focusd on the Hungarian system. Periodica Polytechnica Social and Management Sciences, 16(1), 45-54 (2008). DOI: $10.3311 /$ pp.so.2008-1.05
3 Bouwer M., de Jong K., Jonk M., Berman T., Bersani R., Lusser H., Nissinen A., Parikka K., Szuppinger P., Green Public Procurement in Europe 2005: Status overview. Virage Milieu \& Management B.V., Haarlem, Netherlands (2005). http://ec.europa.eu/environment/GPP/pdf/Stateofplaysurvey2005 en.pdf

4 European Commission; Directorate-General for the Environment, Buying green! A handbook on green public procurement. Official Publications of the European Communities, Luxembourg (2011). DOI: $10.2779 / 74936$ http://ec.europa.eu/environment/gpp/pdf/handbook.pdf 
5 Call for Tenders National Bank of Hungary HU-Budapest,

Nyomdai kivitelezési szolgáltatások 2013/S 036-057515 Ajánlati/részvételi felhivás Szolgáltatásmegrendelés.

http://ted.europa.eu/udl?uri=TED:NOTICE:57515-

2013:TEXT:HU:HTML

6 The European Comission, Communication from the Commission to the European Parliament, The Council, The European Economic and Social Committee and the Committee of the Regions, Energy 2020: A strategy for competitive, sustainable and secure energy. $\operatorname{COM}(2010) 639$ final, Brussels (2010).

http://eur-lex.europa.eu/LexUriServ/LexUriServ. do? uri=COM:2010:0639:FIN:EN:PDF

7 Commission of the european communities, Communication from the Commission to the European Parliament, The Council, The European Economic and Social Committee and the Committee of the Regions, Public procurement for a better environment. COM(2008) 400 final, Brussels (2008).

http://eur-lex.europa.eu/LexUriServ/LexUriServ. do?uri=COM:2008:0400:FIN:EN:PDF

8 Diófási O., Green Public Procurement as a Driver of Sustainable Consumption. in ,Management and Environmental Protection' (ed. Barbu C.,) ASERS Publishing House (2012).

9 Diófási O., Valkó L., Facing green consumers: Answering the challenge and taking the advantage. International Journal of Sales, Retailing and Marketing, Special Issue: Selected papers from the 9th CIRCLE Conference, 42-50 (2012). DOI: $10.5848 / \mathrm{APBJ} .2012 .00011$

10 Diófási O., Valkó L., Training methods for purchasing officers to facilitate green procurement in Hungary. in ,3rd International Symposium on Environmental Management, SEM - Towards Sustainable Technologies. Zagreb, Croatia', (eds.: Koprivanac N., Kusic H., Bozic L.) (2011).

11 European Parliament and Council, Directive 2004/17/EC of the European Parliament and of the Council of 31 March 2004 coordinating the procurement procedures of entities operating in the water, energy, transport and postal services sectors. Official Journal of the European Union, L 134/1, 1-113 (2004).

12 European Parliament and Council, Directive 2004/18/EC of the European Parliament and of the Council of 31 March 2004 on the coordination of procedures for the award of public works contracts, public supply contracts and public service contracts. Official Journal of the European Union, L 134/114, 114-240 (2004).

13 European Parliament and Council, Directive 2009/33/EC of the European Parliament and of the Council of 23 April 2009 on the promotion of clean and energy-efficient road transport vehicles. Official Journal of the European Union, L 120/5, 5-12 (2009).

http://eur-lex.europa.eu/LexUriServ/LexUriServ.do?uri=OJ:L:2009:1 20:0005:0012:EN:PDF

14 European Parliament and Council, Directive 2010/31/EU of the European Parliament and of the Council of 19 May 2010 on the energy performance of buildings. Official Journal of the European Union, L 153/13, 13-35 (2010).

http://eur-lex.europa.eu/LexUriServ/LexUriServ.do?uri=OJ:L:2010:1 53:0013:0035:EN:PDF

15 Kunzlik P, EcoProcura 2012. http://www.ecoprocura.eu/fileadmin/editor files/programme/ Presentations/Peter Kunzlik.pdf (Accessed May 2. 2013.)
16 European Environment Agency (EEA), Time for action-towards sustainable consumption and production in Europe: Summary report of the conference held on 27-29 September 2007, Ljubljana, Slovenia. EEA Technical report, No 1/2008 (2008).

DOI: $10.2800 / 15168$

17 European Environmental Bureau website, http://www.eeb.org/index.cfm/activities/sustainability/green-publicprocurement/green-public-procurement-what-is-the-eu-doing/ (Accessed May 15. 2013.)

18 GPP Europe- Case study 31, http://ec.europa.eu/environment/gpp/pdf/news_alert/Issue13 Case Study31_Budapest_Bridge.pdf (Accessed April 22. 2013.)

19 GPP website of Ireland, http://www.greenpublicprocurement.ie/news-and-events/green-publicprocurements-growing-pains/ (Accessed April 20. 2013.)

20 Green Public Procurement (GPP) Europe website, http://ec.europa.eu/environment/gpp/index_en.htm (Accessed May 15. 2013.)

21 Kiss A., Valkó L., Eco-labels in Hungarian Public Procurement. Periodica Polytechnica Social and Management Sciences, 13(2), 107120 (2005).

22 National GPP Strategies (2012. August) http://ec.europa.eu/environment/gpp/pdf/national_gpp_strategies en.pdf (Accessed May 10. 2013.)

23 European Parliament and Council, Regulation (EU) No 174/2013 of the European Parliament and of the Council of 5 February 2013 amending Regulation (EC) No 106/2008 on a Community energyefficiency labelling programme for office equipment. Official Journal of the European Union, L 63/1, 1-4 (2013).

http://eur-lex.europa.eu/LexUriServ/LexUriServ.do?uri=OJ:L:2013:0 63:0001:01:EN:PDF

DOI: 10.3000/19770677.L_2013.063.eng

24 Centre for European Policy Studies (CEPS), The Uptake of Green Public Procurement in the EU 27. Submitted ot the European Commission, DG Environment, (2012). http://ec.europa.eu/environment/gpp/pdf/CEPS-CoE-GPP\%20 MAIN\%20REPORT.pdf

(Accessed September 14. 2012.)

25 The value of green: Collection of statistical information on Green Public Procurement in the EU. Report on data collection results, conducted by PricewaterhouseCoopers, Significant and Ecofys (2009). http://ec.europa.eu/environment/gpp/pdf/statistical_information.pdf (Accessed September 10. 2010.)

26 Valkó L., Csete M., Sustainable consumption. in ,Periodica Oeconomica: Regional Development and Competitiveness' (eds.: Carmona M., János Szlávik J., Zám É.) University of Paris-Sorbonne IV., Eszterházy Károly College, Eger, 93-103 (2008)

27 Zöld beszerzés mintaprojekt a Magyar Nemzeti Bankban. http://survive.hu/Aktualis/Zold beszerzes_mintaprojekt_a_Magyar Nemzeti Bankban.html (Accessed December 6. 2012.)

28 Zöld közbeszerzés kormányrendelet tervezet. (2013). http:// www.kormany.hu/download/2/34/c0000/z\%C3\%B6ld $\% 20$ k\%C3\%B6zbesze $\% \mathrm{C} 3 \% \mathrm{~A} 9 \mathrm{~s}$ honlapra.pdf (Accessed January 30. 2013.) 